\title{
Infection of Onion Leaves by Pantoea ananatis Leads to Bulb Infection
}

Eric A. Carr, Ali M. Zaid, Jean M. Bonasera, James W. Lorbeer, and Steven V. Beer, Department of Plant Pathology and PlantMicrobe Biology, Cornell University, Ithaca, NY 14853

\begin{abstract}
Carr, E. A., Zaid, A. M., Bonasera, J. M., Lorbeer, J. W., and Beer, S. V. 2013. Infection of onion leaves by Pantoea ananatis leads to bulb infection. Plant Dis. 97:1524-1528.

Pantoea ananatis has been identified as a cause of center rot of onion. In the field, onion leaves can become infected with P. ananatis and lead to leaf blight. Infected bulbs often are detected only after harvest; however, it has not been demonstrated experimentally that leaf infection by $P$. ananatis can lead to bulb infection. In this study, onion leaf infection by $P$. ananatis leading to bulb infection was investigated. Of 18 strains of $P$. ananatis isolated from symptomatic onion bulbs grown in New York, 14 were pathogenic in bulb and leaf tissue. Pathogenic strains of $P$. ananatis caused nonmacerated, yellow-brown coloration in

days at $28^{\circ} \mathrm{C}$. Subepidermal inoculation of onion leaves with pathogenic strains of $P$. ananatis resulted in gray-white foliar lesions that extended acropetally and basipetally from the points of inoculation. In all, $16 \%$ of leaf lesions extended to the onion neck and $11 \%$ continued into the bulbs, which developed nonmacerated, yellow-brown scales. Bacteria recovered from the leading edges of lesions had microbiological and molecular characteristics of $P$. ananatis. This is the first experimental evidence that infection of onion leaves by $P$. ananatis can lead to bulb infection.
\end{abstract} fleshy bulb scales following inoculation of bulbs and incubation for 2
Pantoea ananatis, a bacterium belonging to the family Enterobacteriaceae, causes diseases in a wide range of economically important agricultural crops $(6,7,13,16)$, including onion (Allium сера) (9). P. ananatis was first reported to cause center rot of onion in 1997 in Georgia, United States (11); subsequently, the onion disease was reported in Colorado (18), Michigan (9), and New York (4). Initial symptoms in the field appear on the leaves as small, off-white lesions that develop into streaks that can extend the length of the leaves $(4,10)$. Lesions may darken to light brown, become gray, or remain off-white. At first, only one or two of the center leaves display symptoms; however, more leaves may become infected if conditions are favorable. Development of symptoms in onion bulb scales, which are formed from the swollen base of each leaf sheath (2), have been observed in onion bulbs developing in the field (C. A. Hoepting, A. M. Zaid, J. W. Lorbeer, and S. V. Beer, personal communication) and, commonly, after harvest or following storage. Infected bulb scales exhibit yellow-brown coloration; however, bulb tissues remain firm. Although other investigators have reported maceration of bulb tissue that develops following infection with $P$. ananatis (10), it is possible that this was due to colonization by secondary pathogens. The lack of tissue maceration following bulb infection by $P$. ananatis as a primary pathogen is different from the soft-rot symptoms seen in onion bulbs infected by pathogens such as Burkholderia cepacia $(3,9,15,20)$.

The development of center rot symptoms in onion bulbs during storage poses a significant problem for growers in New York and many other states and countries where storage onion crops are produced, because onion bulbs often are stored for months prior to

Corresponding author: S. V. Beer, E-mail: svb1@ cornell.edu

* The $\boldsymbol{e}$-Xtra logo stands for "electronic extra" and indicates that a supplementary figure is available online.

Accepted for publication 27 May 2013.

http://dx.doi.org/10.1094/PDIS-06-12-0597-RE

(c) 2013 The American Phytopathological Society grading and marketing (J. W. Lorbeer, personal communication). Because onion bulbs that are infected solely by $P$. ananatis remain firm and exhibit subtle or no external symptoms, they can be difficult to detect on grading lines. Thus, bulbs infected by $P$. ananatis can be packed and shipped to market. Upon receiving shipments, inspectors usually sample onions by cutting a sample of bulbs to reveal the internal condition and check for evidence of internal decay. If sufficient infection is detected, an inspector may reject the entire shipment, which can constitute a substantial economic loss for the onion grower (5).

The majority of research on the onion center rot pathogen has focused on the foliar aspects of the disease. There have been numerous reports describing onion leaf symptoms caused by $P$. ananatis in the field or under greenhouse and laboratory conditions $(11,12,19)$. Furthermore, most published pathogenicity tests for $P$. ananatis and a closely related bacterium, P. agglomerans, in onion have relied on the development of leaf symptoms $(8,10,11,14)$. Consequently, bulbs were rarely examined for symptoms. However, based on the recent identification of $P$. ananatis as a causal agent of center rot in New York (4), a more thorough study of the bulb decay aspect of the disease was warranted.

Although the progression of infection in onion plants by $P$. ananatis from the foliage to the bulb is often assumed or observed anecdotally, the progression from leaves to bulbs has not been demonstrated experimentally. Additionally, published descriptions of center-rot-associated bulb decay caused by $P$. ananatis observed in other states described symptoms as "rotted bulbs" $(9,10)$. However, "bulb rot" typically is considered to include softening or maceration of bulb tissue that can become moist and foul-smelling $(3,9)$, which is consistent with secondary bacterial and yeast infections $(8,9,18)$. Such symptoms differ from those observed in material infected exclusively with $P$. ananatis in New York (4). Perhaps because secondary rot of onion bulbs can be common (5), investigators have reported that the incidence of center rot symptoms in onion foliage observed in the field does not appear to be related to the incidence of bulb rot symptoms associated with $P$. ananatis infection (12). Therefore, the goal of this study was to test the hypothesis that leaf infections caused by $P$. ananatis can lead to bulb symptoms characteristic of center rot. We also determined whether 
strains of $P$. ananatis can be pathogenic in both onion leaf and bulb tissues, and monitored the movement of the pathogen from inoculated leaves into bulb tissues.

\section{Materials and Methods}

Bacterial isolation. Onion bulbs of unknown yellow globe cultivars that had been grown in and harvested from muckland soils by experienced New York onion growers using standard techniques for the region (http://www.nysaes.cals.cornell.edu/recommends/ 21 frameset.html) were collected from four farm storages during 2007, 2008, and 2009. Most bulbs sampled had been stored at $4^{\circ} \mathrm{C}$ for 2 to 6 months before bacterial isolations were attempted. A slightly depressed bulb top indicated the possible presence of a bacterial infection, such as center rot. Therefore, symptomatic (discolored) tissues from such bulbs (Fig. 1) were sampled for bacteria. Onion bulbs were bisected longitudinally and each half of the bulb was cut into quarters with a disinfested blade. Inner fleshy scales appearing healthy were removed with forceps to expose symptomatic scales. Approximately $8 \mathrm{~mm}^{3}$ of tissue from symptomatic scales was then removed and macerated using a sterile scalpel; the macerate dilution-streaked onto nutrient agar (NA) (17) and a semiselective medium for P. ananatis (PA 20) (14), and the plates were incubated in the dark at $28^{\circ} \mathrm{C}$ for 1 to 3 days. Pure cultures of 18 bacterial strains isolated from onion bulbs grown in New York were stored at $-80^{\circ} \mathrm{C}$ in $1.5-\mathrm{ml}$ sterile tubes containing $1.0 \mathrm{ml}$ of $15 \%$ ( $\mathrm{vol} / \mathrm{vol}$ ) glycerol in water (Table 1). Reference strains of $P$. ananatis (97-1, PNA07-1, and PNA07-2) were obtained from R. D. Gitiatis (University of Georgia). Strain OC5a (4) was used as an additional reference strain from New York. A strain of B. cepacia pathogenic to onion was used as a control treatment to induce and demonstrate macerated bulb tissue (Table 1).

Inoculum preparation. Inocula for pathogenicity tests with each bacterial isolate were prepared from cultures stored at $-80^{\circ} \mathrm{C}$. Bacteria were streaked on NA and incubated in the dark at $26^{\circ} \mathrm{C}$ for $24 \mathrm{~h}$. A bacterial suspension for leaf and bulb inoculations was prepared in sterile water for each strain to achieve an optical den- sity at $600 \mathrm{~nm}\left(\mathrm{OD}_{600}\right)=0.20$, which corresponds to approximately $10^{8} \mathrm{CFU} / \mathrm{ml}$. In addition, 10 -fold serial dilutions of inocula were prepared in sterile water to approximately $10^{4} \mathrm{CFU} / \mathrm{ml}$, as needed.

Plant material. Asymptomatic, yellow-globe onion bulbs grown in Orange County, NY and onion sets (small bulbs that are planted instead of seed to reduce the time from planting to harvest) of five different cultivars ('Forum', 'Nube', 'Red Bull', 'Sherman', and 'Talon') obtained from Bejo Seeds, Inc. were used for pathogenicity tests. Individual sets were planted in Cornell potting medium (1), with the basal plate positioned approximately $5 \mathrm{~cm}$ below the soil surface in 15 -cm-diameter pots. Plants received water every 2 days, NPK soluble fertilizer (21-5-20) at $300 \mathrm{ppm}$ twice a week, and Spinosad insecticide (Gnatrol WDG; Valent Professional Products) at $2 \mu \mathrm{l} /$ liter ( $26 \mathrm{oz}$. per 100 gal.) applied biweekly by spraying the foliage against thrips. Onion sets were planted and grown under greenhouse conditions during different times of the year for different experiments. The specific conditions for each experiment are discussed below.

For leaf inoculation tests, onion plants were grown from sets (Talon) under greenhouse conditions at Ithaca NY from April to July for 5 to 7 weeks for adequate leaf development. Leaf inoculations were made during that period as well. For experiments designed to monitor bulb infections from leaf infections, onion plants (Forum) were grown under greenhouse conditions from December to March with $14 \mathrm{~h}$ of supplemental lighting from $400-\mathrm{W}$, highpressure sodium lamps. The temperature was set at $27^{\circ} \mathrm{C}$ but was not monitored for daily fluctuations. All other growing conditions were as stated above. Three replicate experiments were designed to follow the development of bulb infections from leaf infections (see below); however, all onion sets for these experiments were planted on the same day in December. To avoid differences in the growth rates of onion sets, which might have confounded the treatments evaluated, plants with six leaves were selected for leaf inoculation for each of the three replicate experiments. As a result, trials 2 and 3 began 3 and 6 days, respectively, after trial 1 .

Effective bacterial titer for inoculation. Prior to pathogenicity tests, the effective titer of strains OC5a and 97-1 required for in-

Table 1. Pathogenicity of bacterial strains inoculated into onion leaves, bulbs, and sets

\begin{tabular}{|c|c|c|c|c|}
\hline \multirow[b]{2}{*}{ CUCPB number } & \multirow[b]{2}{*}{ Strain } & \multirow[b]{2}{*}{ Source } & \multicolumn{2}{|c|}{ Pathogenicity in ${ }^{a}$} \\
\hline & & & Bulbs and sets & Leaves \\
\hline \multicolumn{5}{|c|}{ Pantoea ananatis strains $\mathrm{s}^{\mathrm{c}}$} \\
\hline 6829 & OC5a & Onion bulb & + & + \\
\hline 6831 & OC $34 \mathrm{~b}$ & Onion bulb & - & $\mathrm{nt}$ \\
\hline 6833 & OC37 & Onion bulb & - & $\mathrm{nt}$ \\
\hline 6834 & OC39a & Onion bulb & + & + \\
\hline 6835 & $\mathrm{OC} 42$ & Onion bulb & - & _- \\
\hline 6836 & OC53 & Onion bulb & + & + \\
\hline 6837 & OC75 & Onion bulb & + & + \\
\hline 6838 & OC81 & Onion bulb & + & + \\
\hline 6840 & OC85 & Onion bulb & + & + \\
\hline 6841 & OC86 & Onion bulb & + & + \\
\hline 6842 & OC105 & Onion bulb & + & + \\
\hline 6843 & OC110 & Onion bulb & + & + \\
\hline 6844 & OC113 & Onion bulb & + & + \\
\hline 6845 & $\mathrm{OC} 120$ & Onion bulb & + & + \\
\hline 6846 & OC132 & Onion bulb & + & + \\
\hline 6847 & OC134b & Onion bulb & + & + \\
\hline 6848 & OC136 & Onion bulb & - & $\mathrm{nt}$ \\
\hline 6850 & OC144 & Onion bulb & + & $\mathrm{nt}$ \\
\hline \multicolumn{5}{|l|}{ Reference strains } \\
\hline 3372 & Burkholderia cepacia, ATCC 17759 & Onion, New York & $t^{\mathrm{d}}$ & - \\
\hline 6790 & P. ananatis, $97-1$ & Onion, Georgia & + & + \\
\hline 6865 & P. ananatis, PAN07-1 & Onion, Georgia & + & + \\
\hline 6866 & P. ananatis, PAN07-2 & Onion, Georgia & + & + \\
\hline
\end{tabular}

a Symbols: $+=$ symptoms that developed were similar to those caused by $P$. ananatis reference strain $97-1,-=$ tissue remained symptomless following inoculation in all three repeats of the experiment, and $n t=$ not tested.

${ }^{\mathrm{b}}$ Cornell University Collection of Phytopathogenic Bacteria (CUCPB), Ithaca, NY, reference number.

${ }^{c} P$. ananatis strains isolated in New York State from 2007 to 2009.

${ }^{\mathrm{d}}$ Infected bulb tissue became macerated and produced a vinegary odor more typical of sour skin caused by Burkholderia cepacia or by infection with yeast, than is typical of center rot (9). 
ducing infection in sets and leaves was determined. Bacterial suspensions were prepared as described above and 10-fold serial dilutions were made in sterile water. Then, $30 \mu \mathrm{l}$ of each dilution was injected into three replicate onion sets (Talon) or into two leaves each of three onion plants, as described below. Control treatments were inoculated with sterile water. Inoculated sets were incubated in the dark at $28^{\circ} \mathrm{C}$ for 2 to 7 days, and plants were incubated in the greenhouse for 7 days. Plant reaction was recorded as positive or negative compared with plants treated with sterile water. Differences in plant reaction among dilutions were determined for each leaf and bulb or set inoculation test using the Tukey-Kramer honestly significant difference test (JMP Pro 9.0; SAS Institute Inc.).

Pathogenicity tests in bulbs and sets. The pathogenicity of the strains of $P$. ananatis listed in Table 1 was evaluated by incubating onion bulbs, sets, and leaves following inoculation, and comparing the results with the reference strains 97-1 and OC5a. Mature onion bulbs, approximately $7.5 \mathrm{~cm}$ in diameter, were surface disinfested prior to inoculation by submerging each bulb in $0.6 \%$ sodium hypochlorite (wt/vol) for $3 \mathrm{~s}$; onion sets were surface-disinfested by submerging each set in $70 \%$ ethanol ( $\mathrm{vol} / \mathrm{vol})$ for $1 \mathrm{~s}$. Bulbs and sets were then air dried. A suspension of each strain of P. ananatis $(30 \mu \mathrm{l})$ was injected into the side of each of three replicate onion bulbs and three replicate onion sets, using a 26-gauge, $12.7-\mathrm{mm}$ long hypodermic needle and 1-ml syringe. Inoculated plant material was placed individually into cells of plastic trays $(8$ by 8 by 6 $\mathrm{cm}$, length by width by height, respectively, of the cells for onion bulbs; and 3 by 3 by $4 \mathrm{~cm}$ for onion sets) before incubating in the dark at $28^{\circ} \mathrm{C}$ for 2 to 7 days. Sterile water $(30 \mu \mathrm{l})$ and a strain of $B$. cepacia $\left(30 \mu \mathrm{l}\right.$ of a bacterial suspension in water at $\left.\mathrm{OD}_{600}=0.20\right)$ were used as negative control treatments. Bulb and set inoculation experiments were carried out three times. Bulb and set reactions were recorded as positive or negative compared with symptoms induced by the two reference strains of $P$. ananatis (Fig. 1). Bacteria were isolated from infected bulbs and sets onto PA 20 agar as described above, and the identity of the isolates as $P$. ananatis was assessed using biochemical tests and the size of the polymerase chain reaction (PCR) amplicon (398 bp) of the 16S-23S ribosomal DNA internal transcribed spacer region, as described previously (4).

Pathogenicity tests in leaves. Leaves of onion plants grown from sets (Talon) in the greenhouse were inoculated with strains of $P$. ananatis and observed for subsequent symptom development. Approximately $30 \pm 10 \mu \mathrm{l}$ of inoculum of the appropriate bacterial strain was injected into the subepidermal leaf area of the third and fourth youngest leaves of each plant, approximately $3 \mathrm{~cm}$ above the neck, using a 26-gauge, 12.7-mm-long hypodermic needle and $1-\mathrm{ml}$ syringe. Plants were then incubated under greenhouse conditions for 7 days. Leaves were approximately $23 \mathrm{~cm}$ in length when inoculated. Control plants were injected similarly with sterile water. Leaf inoculation experiments were carried out three times with a minimum of three replicate plants for each treatment in each experiment. Plant reactions were recorded as positive or negative compared with symptoms induced by reference strains of $P$. ananatis. Bacteria were isolated from infected leaves by excising and macerating the margins of lesions (without first disinfesting the leaf surface) and plating the macerate on PA 20 agar. The identification of the resulting colonies was assessed using biochemical tests and PCR assays, as previously reported (4).

Measurement of disease progression from leaf to bulb. To monitor the progression of center rot symptoms from infected leaves into onion bulb tissue, the second youngest leaf of 40 replicate onion plants (Forum) was inoculated with $30 \mu \mathrm{l}$ of a suspension of $P$. ananatis strain OC5a, as described above. Leaves were approximately $15 \mathrm{~cm}$ in length when inoculated. Three replicate experiments were conducted, each in a completely randomized design. Plants were incubated in a greenhouse from January to March, as described above. Plants were watered three times a week. Sterile water was injected into 40 replicate onion plants as a negative control treatment. Onion plants were harvested destructively 46 to 52 days after inoculation, at which time each plant was assessed visually for symptoms in the leaves, neck, and bulb. Infection was recorded as positive or negative based on the presence or absence of symptoms. Attempts were made to isolate $P$. ananatis from symptomatic neck and bulb tissues onto PA 20 agar, as described above. The nominal logistic model and a $\chi^{2}$ test (JMP Pro

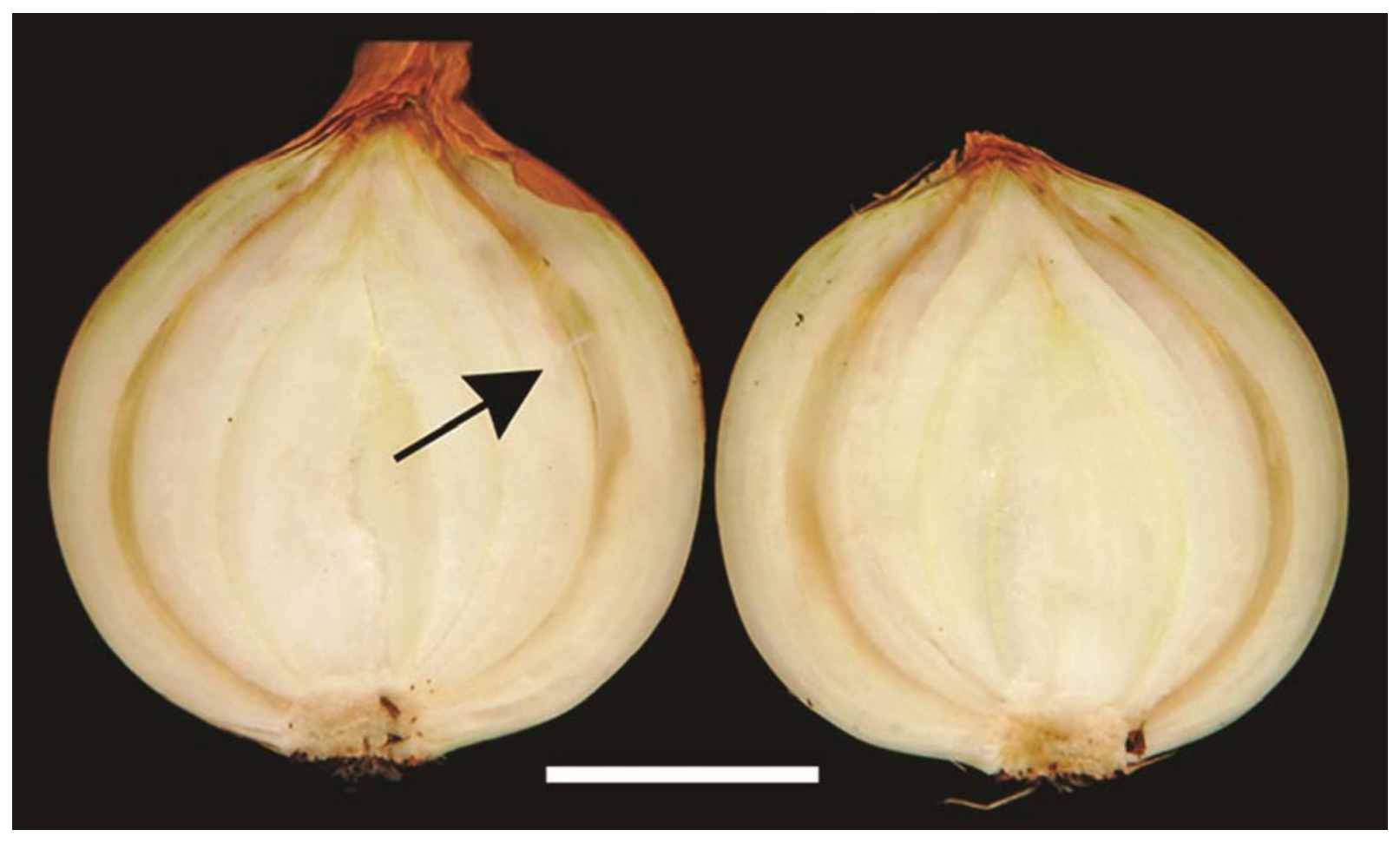

Fig. 1. Onion bulb obtained from storage, bisected longitudinally, and suspected of being infected with the center rot pathogen, Pantoea ananatis. The bulb was grown in New York State in 2008. P. ananatis was isolated from the bulb. Note that only one fleshy scale is symptomatic, and that scale appears yellow-brown in color but is not macerated. $\mathrm{Bar}=3 \mathrm{~cm}$. 
9.0; SAS Institute Inc.) were used to determine significant effects of replicates within experiments and replicate trials, as well as the significant effect of the inoculation treatments.

\section{Results}

Effective titer for onion set and leaf inoculations. There was no significant $(P<0.05)$ difference in infection induced by similar concentrations of $P$. ananatis strains OC5a and 97-1 in either onion sets or leaves (data not shown). The dilution endpoint for infection to occur in onion sets and leaves was $30 \mu \mathrm{l}$ of $\geq 10^{6} \mathrm{CFU} / \mathrm{ml}$ (i.e., onion sets and leaves did not exhibit symptoms following inoculation with $30 \mu \mathrm{l}$ of $\leq 10^{5} \mathrm{CFU} / \mathrm{ml}$ per set or leaf). Sets and leaves inoculated with $30 \mu \mathrm{l}$ of $\geq 10^{6} \mathrm{CFU} / \mathrm{ml}$ displayed symptoms similar to those inoculated with $30 \mu \mathrm{l}$ of $10^{7}$ or $10^{8} \mathrm{CFU} / \mathrm{ml}$ (data not shown).

Bulb and set infections. Onion sets reacted similarly to mature onion bulbs when inoculated with $P$. ananatis (Supplementary Figure 1). Additionally, all reference strains of $P$. ananatis reacted similarly when inoculated in onion bulbs, sets, and leaves (Table 1); therefore, $P$. ananatis strain $97-1$ was used as the primary reference strain, and it is designated as such. Strains OC5a and 97-1 reacted indistinguishably when inoculated into onion bulbs and sets of all five cultivars. Bulbs and sets injected with sterile water remained symptomless. Disease symptoms were observed as early as 2 days after inoculation. As incubation time increased, infected tissue became darker and lesions extended beyond the site of inoculation. Typical symptoms in infected scales included yellowbrown coloration of fleshy scales without maceration. Of 18 strains of $P$. ananatis isolated from New York onion bulbs, 14 strains caused typical symptoms of center rot following inoculation into healthy onion leaves and sets (Table 1). Bacteria reisolated from inoculated, symptomatic bulbs and sets were identical to the strains inoculated, based on growth characteristics on PA 20 agar and the apparent size of the PCR amplicon compared with that of the reference strain.

Leaf infections. Of 14 New York strains of $P$. ananatis inoculated in onion leaves, 13 strains caused leaf infection (Table 1). Leaves injected with sterile water remained symptomless. Typical symptoms consisted of gray-white lesions that developed within 5 days of inoculation. Within 7 days, necrotic lesions extended acropetally and basipetally from the points of inoculation; however, lesion development was observed visually to occur at different rates. Bacteria reisolated from inoculated, symptomatic leaves appeared identical to the strains inoculated initially, based on growth characteristics on PA 20 agar and the apparent size of the PCR amplicon compared with that of the reference strain.

Association of leaf infection with bulb infection. All 16 strains tested for pathogenicity in both onion bulb and leaf tissues were pathogenic in both bulb and leaf tissues following inoculation (Table 1). Among three replicate trials and for each site of infection (bulb versus leaf), there was no significant effect among replications within repeat trial replicates $(P=1.0000$ for incidence of leaf infection, $P=0.9860$ for incidence of neck infection, and $P=$ 0.9998 for incidence of bulb infection) and no significant differences among the repeat trials $(P=1.0000$ for all infection locations) according to the nominal logistic model, $\chi^{2}$ analysis. There-
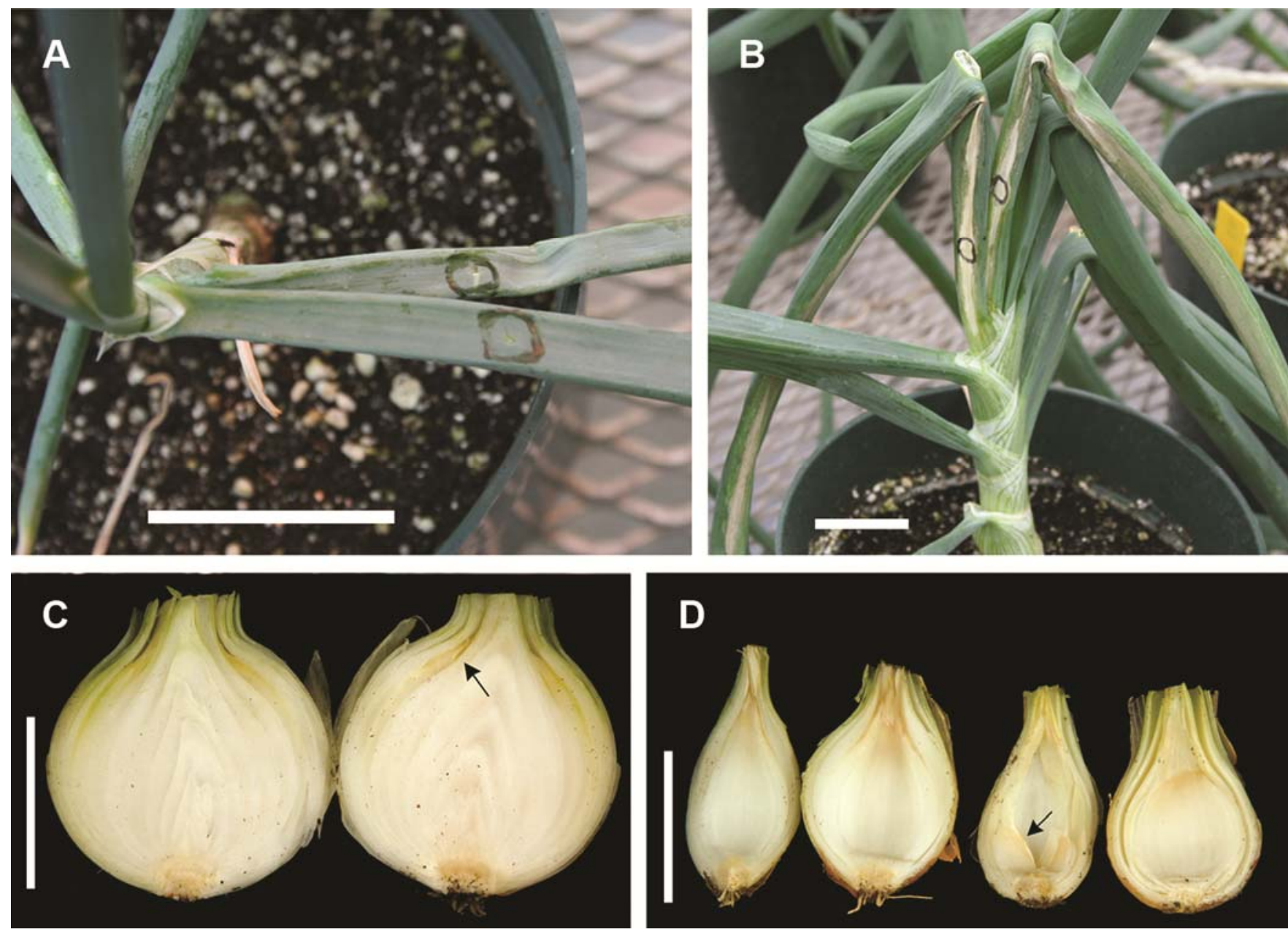

Fig. 2. Symptoms resulting from inoculation of onion leaves with $\mathbf{A}$, water and $\mathbf{B}$, Pantoea ananatis strain $0 \mathrm{C} 5 \mathrm{a}\left(10^{8} \mathrm{CFU} / \mathrm{ml}\right.$ at an optical density at $\left.600 \mathrm{~nm}=0.20\right)$. The third and fourth youngest leaves were inoculated with $30 \mu \mathrm{l}$ of inoculum in the summer in a greenhouse. Black circles indicate the location of the needle puncture on each leaf C, Symptomatic bulb scales (arrow) following leaf inoculation and incubation of the plants for 2 weeks. D, Infection on $>75 \%$ of the individual bulb scales resulted in "splitting" of the scales (arrow). Bars $=4 \mathrm{~cm}$. 
fore, infection data from the three replicate trials were pooled for analysis for each dependent variable. Treatment (inoculation with bacteria or sterile water) had a significant effect at all three sites of infection $(P<0.0001)$. No symptoms were observed in watertreated control plants. Leaf infection was present in $97 \pm 1.6 \%$ (mean \pm standard error) of plants inoculated with $P$. ananatis. By 50 days after inoculation, $16 \pm 3.3 \%$ of plants inoculated with $P$. ananatis exhibited infection in the neck and, of the leaf infections induced by $P$. ananatis, infection was also present in $11 \pm 2.8 \%$ of the onion bulbs. Additionally, leaf infection leading to bulb infection appeared to have a continuous infection from one tissue to the other. In all plants with bulb symptoms, the bulb scales that became infected were from the specific leaves inoculated. The most common bulb symptom was yellow-brown coloration in one scale near the neck and top of the bulb (Fig. 2C). In approximately $75 \%$ of the symptomatic bulbs, $>90 \%$ of the individual bulb scale tissue exhibited yellow-brown coloration that often led to splitting of the infected scale (Fig. 2D). Bacteria reisolated from symptomatic necks and bulb scales were identical to the inoculated strain based on growth characteristics on PA 20 and the apparent size of the PCR amplicon compared with that of the reference strain.

\section{Discussion}

The symptoms of onion leaf and bulb infections caused by $P$. ananatis have been described previously $(4,11,12,19)$ but the relationship between symptoms in the two parts of onion plants had not been established experimentally. In this study, the pathogenicity of 18 strains of $P$. ananatis isolated from onion in New York first was tested in both leaf and bulb tissues. Four strains were identified as nonpathogenic in bulb or leaf tissue. Strains consistently pathogenic in leaf tissue also were pathogenic on bulb tissue. Leaves of growing onion plants developed symptoms resembling center rot, as observed in Georgia (11) and elsewhere $(4,18)$, following inoculation with $P$. ananatis. Leaf lesions progressed from the point of inoculation into the necks of a subset of the inoculated plants, and then into developing bulb scales. In the infected bulb scales, the yellow-brown coloration occurred without maceration, demonstrating the association between the two distinct phases of center rot caused by $P$. ananatis (18).

Additional details of the mode of infection of onion plants by $P$. ananatis were examined in this study; for example, the lack of movement of the bacterium between adjacent fleshy bulb scales. After leaf infection progressed into the neck tissue, the corresponding bulb scale also became infected and the number of infected bulb scales did not exceed the number of leaves inoculated. This indicated that the pathogen did not move between adjacent bulb scales. This also suggests that center rot bulb infection, typically discovered following storage of onion bulbs, likely is initiated by infection of the corresponding leaf during the growing season. If this is the case, control of foliar stages of infection might reduce the incidence of $P$. ananatis-associated bulb infection in storage.

The age of onion plants or leaves inoculated may affect the rate of symptom development. For instance, in preliminary experiments conducted during summer months, center rot bulb symptoms following inoculation of the fourth or fifth oldest leaf were observed as early as 2 weeks after inoculation (data not shown). Additionally, lesions expanded approximately $2.5 \mathrm{~cm} /$ day, and more than $55 \%$ of the inoculated leaves were necrotic and had collapsed by 2 weeks after inoculation. However, during winter months, center rot bulb symptoms were only observed approximately 7 weeks after leaf inoculation. Leaf age might account for the differences in the period after inoculation before the appearance of bulb symptoms, because it appears that infections of older leaves (2 to 3 months old) with $P$. ananatis may progress to the bulb more rapidly than those of relatively younger leaves (1 month old). Alternatively, differences in greenhouse temperatures or light intensity in the summer versus winter months of this study also might account for the differences in the rate of symptom development observed.
The progression of $P$. ananatis from onion leaves to bulbs revealed in this study has implications for onion growers in New York and elsewhere. Foliar infections may portend levels of subsequent bulb infection; however, no data relating these two phases existed for onion produced commercially in New York and elsewhere prior to this study. If a similar positive relationship can be demonstrated under field conditions as well, and plants with leaf infection can be identified prior to or at harvest, the proportion of infected bulbs placed in storage and subsequently shipped to markets might decrease. As a consequence, control of the foliar phase of center rot may prove useful in preventing infection of onion bulbs in storage. Future studies under field conditions might explore these possibilities.

\section{Acknowledgments}

This research was supported, in part, by the New York Onion Research and Development Program. We thank S. C. D. Carpenter and P. T. Hyde for their review of earlier drafts and several helpful suggestions; and Bejo Seeds, Inc., Geneva, NY, for the donation of onion sets used in this study.

\section{Literature Cited}

1. Boodley, J., and Sheldrake, R. 1972. Cornell peat-lite mixes for commercial plant growing. Cornell Univ. Coop. Ext. Inf. Bull. 43:1-8.

2. Brewster, J. L. 2008. Onions and Other Vegetable Alliums. CABI, Cambridge.

3. Burkholder, W. H. 1950. Sour skin, a bacterial rot of onion bulbs. Phytopathology 40:115-117.

4. Carr, E. A., Bonasera, J. M., Zaid, A. M., Lorbeer, J. W., and Beer, S. V. 2010. First report of bulb disease of onion caused by Pantoea ananatis in New York. Plant Dis. 94:916.

5. Ceponis, M. J., Cappellini, R. A., and Lightner, G. W. 1986. Disorders in onion shipments to the New York market, 1972-1984. Plant Dis. 70:988991.

6. Cother, E. J., Reinke, R., McKenzie, C., Lanoiselet, V. M., and Noble, D. H 2004. An unusual stem necrosis of rice caused by Pantoea ananas and the first record of this pathogen on rice in Australia. Australas. Plant Pathol. 33:495-503.

7. Coutinho, T. A., Preisig, O., Mergaert, J., Cnockaert, M. C., Riedel, K. H., Swings, J., and Wingfield, M. J. 2002. Bacterial blight and dieback of Eucalyptus species, hybrids, and clones in South Africa. Plant Dis. 86:20-25.

8. Edens, D. G., Gitaitis, R. D., Sanders, F. H., and Nischwitz, C. 2006. First report of Pantoea agglomerans causing a leaf blight and bulb rot of onions in Georgia. Plant Dis. 90:1551.

9. Gent, D. H., Schwartz, H. F., and Mohan, S. K. 2008. Center Rot. Pages 64 66 in: Compendium of Onion and Garlic Diseases and Pests, 2nd ed. H. F. Schwartz and S. K. Mohan, eds. American Phytopathological Society, St. Paul, MN.

10. Gitaitis, R., Walcott, R., Culpepper, S., Sanders, H., Zolobowska, L., and Langston, D. 2002. Recovery of Pantoea ananatis, causal agent of center rot of onion, from weeds and crops in Georgia, USA. Crop Prot. 21:983989.

11. Gitaitis, R. D., and Gay, J. D. 1997. First report of a leaf blight, seed stalk rot, and bulb decay of onion by Pantoea ananas in Georgia. Plant Dis. $81: 1096$.

12. Gitaitis, R. D., Walcott, R. R., Wells, M. L., Perez, J. C. D., and Sanders, F. H. 2003. Transmission of Pantoea ananatis, causal agent of center rot of onion, by tobacco thrips, Frankliniella fusca. Plant Dis. 87:675-678.

13. Goszczynska, T., Botha, W. J., Venter, S. N., and Coutinho, T. A. 2007 Isolation and identification of the causal agent of brown stalk rot, a new disease of maize in South Africa. Plant Dis. 91:711-718.

14. Goszczynska, T., Venter, S. N., and Coutinho, T. A. 2006. PA 20, a semiselective medium for isolation and enumeration of Pantoea ananatis. J. Microbiol. Methods 64:225-231.

15. Kawamoto, S. O., and Lorbeer, J. W. 1964. Selective isolation of soft-rot bacteria of onion. Phytopathology 54:897-901.

16. Kido, K., Adachi, R., Hasegawa, M., Yano, K., Hikichi, Y., Takeuchi, S. Atsuchi, T., and Takikawa, Y. 2008. Internal fruit rot of netted melon caused by Pantoea ananatis (= Erwinia ananas) in Japan. J. Gen. Plant Pathol. 74:302-312.

17. Schaad, N. W., Jones, J. B., and Chun, W. 2001. Laboratory Guide for the Identification of Plant Pathogenic Bacteria, 2nd ed. American Phytopathological Society, St. Paul, MN.

18. Schwartz, H. F., and Otto, K. 2000. First report of a leaf blight and bulb decay of onion by Pantoea ananatis in Colorado. Plant Dis. 84:808.

19. Walcott, R. R., Gitaitis, R. D., Castro, A. C., Sanders, F. H., and Diaz-Perez, J. C. 2002. Natural infestation of onion seed by Pantoea ananatis, causal agent of center rot. Plant Dis. 86:106-111.

20. Yohalem, D. S., and Lorbeer, J. W. 1997. Distribution of Burkholderia cepacia phenotypes by niche, method of isolation and pathogenicity to onion. Ann. Appl. Biol. 130:467-479. 